\title{
Temozolomide- and fotemustine-induced apoptosis in human malignant melanoma cells: response related to MGMT, MMR, DSBs, and p53
}

\author{
SC Naumann', WP Roos', E Jöst', C Belohlavek', V Lennerz², CW Schmidt' ${ }^{3}$ M Christmann' and B Kaina*,I \\ 'Department of Toxicology, University of Mainz, Mainz, Germany; ${ }^{2}$ Third Department of Internal Medicine, University of Mainz, Mainz, Germany; \\ ${ }^{3}$ Queensland Institute of Medical Research, Queensland, Australia
}

Malignant melanomas are highly resistant to chemotherapy. First-line chemotherapeutics used in melanoma therapy are the methylating agents dacarbazine (DTIC) and temozolomide (TMZ) and the chloroethylating agents BCNU and fotemustine. Here, we determined the mode of cell death in II melanoma cell lines upon exposure to TMZ and fotemustine. We show for the first time that TMZ induces apoptosis in melanoma cells, using therapeutic doses. For both TMZ and fotemustine apoptosis is the dominant mode of cell death. The contribution of necrosis to total cell death varied between 10 and $40 \%$. The $O^{6}$-methylguanine-DNA methyltransferase (MGMT) activity in the cell lines was between 0 and $1100 \mathrm{fmol} \mathrm{mg}{ }^{-1}$ protein, and there was a correlation between MGMT activity and the level of resistance to TMZ and fotemustine. MGMT inactivation by $0^{6}$-benzylguanine sensitized all melanoma cell lines expressing MGMT to TMZ and fotemustine-induced apoptosis, and MGMT transfection attenuated the apoptotic response. This supports that $O^{6}$-alkylguanines are critical lesions involved in the initiation of programmed melanoma cell death. One of the cell lines (MZ7), derived from a patient subjected to DTIC therapy, exhibited a high level of resistance to TMZ without expressing MGMT. This was related to an impaired expression of $\mathrm{MSH} 2$ and $\mathrm{MSH}$ 6. The cells were not cross-resistant to fotemustine. Although these data indicate that methylating drug resistance of melanoma cells can be acquired by down-regulation of mismatch repair, a correlation between $\mathrm{MSH} 2$ and $\mathrm{MSH} 6$ expression in the different lines and $\mathrm{TMZ}$ sensitivity was not found. Apoptosis in melanoma cells induced by TMZ and fotemustine was accompanied by double-strand break (DSB) formation (as determined by $\mathrm{H} 2 \mathrm{AX}$ phosphorylation) and caspase-3 and -7 activation as well as PARP cleavage. For TMZ, DSBs correlated significantly with the apoptotic response, whereas for fotemustine a correlation was not found. Melanoma lines expressing p53 wild-type were more resistant to $\mathrm{TMZ}$ and fotemustine than p53 mutant melanoma lines, which is in marked contrast to previous data reported for glioma cells treated with TMZ. Overall, the findings are in line with the model that in melanoma cells TMZ-induced $\mathrm{O}^{6}$-methylguanine triggers the apoptotic (and necrotic) pathway through DSBs, whereas for chloroethylating agents apoptosis is triggered in a more complex manner.

British Journal of Cancer (2009) I 00, 322 - 333. doi:I0.1038/sj.bjc.6604856 www.bjcancer.com

Published online 6 January 2009

(c) 2009 Cancer Research UK

Keywords: temozolomide; fotemustine; melanoma therapy; apoptosis; MGMT; mismatch repair

Melanoma is among the top six cancers responsible for cancerrelated mortality worldwide (Balch et al, 2001). Once melanoma metastasises treatment outcome is poor. Only a few chemotherapeutic agents have been shown to be active in the treatment of melanomas. The most often used drug is dacarbazine (DTIC), which needs metabolic activation to generate the active DNAmethylating carbenium ions inside the cell (Hill, 1975). Temozolomide (TMZ), which is a triazene derivative that needs no metabolic activation, also has activity in melanoma cells. It hydrolyses spontaneously in aqueous solution, giving rise to the active metabolite 5-(3,3-methyltriazen-1-yl)imidazole-4-carboxa-

*Correspondence: Dr B Kaina, Department of Toxicology, University of Mainz, Obere Zahlbacher Str. 67, D-55I 31 Mainz, Germany;

E-mail: kaina@uni-mainz.de

Revised 13 November 2008; accepted 5 December 2008; published online 6 January 2009 mide that further decomposes to yield DNA-methylating species (Newlands et al, 1997). The response rate after treatment with these methylating drugs is $\sim 20 \%$ (Newlands et al, 1992; Bleehen et al, 1995; Middleton et al, 2000). Temozolomide penetrates well the blood-brain barrier and, therefore, it is also used for the treatment of brain metastases of melanomas (Bael et al, 2008). It can be administered orally and is well tolerated.

An important mechanism of resistance to methylating agents is DNA repair mediated by the damage-reversal suicide enzyme $\mathrm{O}^{6}$ methylguanine-DNA methyltransferase (MGMT). It repairs the pre-toxic DNA lesion $\mathrm{O}^{6}$-methylguanine $\left(\mathrm{O}^{6} \mathrm{MeG}\right)$ by transfer of the methyl group from guanine to an own cysteine residue (Pegg, 2000). This causes, in an expression-dependent manner, resistance to methylating agents that produce $0^{6} \mathrm{MeG}$ (Kaina et al, 1991). Similar to malignant gliomas, melanomas express, compared to other cancers, quite low levels of MGMT (Chen et al, 1992; Kaina et al, 2007), which might explain why melanomas respond to the 
methylating drugs DTIC and TMZ, but not to many other anticancer drugs. In view of the role of MGMT in the defence against $\mathrm{O}^{6} \mathrm{MeG}$ one might anticipate that MGMT determines the clinical outcome in melanoma therapy with methylating drugs. However, conflicting data have been reported. Thus, the pretreatment levels of MGMT in biopsies of cutaneous tumours were not related to the outcome (Middleton et al, 1998) whereas a later study showed that MGMT expression in melanoma metastases was related to the clinical response of the patients to DTIC-based therapy (Ma et al, 2002a, 2003). Conversely, MGMT promoter methylation was not clearly related to the patients response upon TMZ treatment, although methylation threshold levels were also discussed to have an impact on therapy (Rietschel et al, 2008). It appears that melanoma cells are intrinsically resistant and acquire drug resistance by different strategies (Soengas and Lowe, 2003) in which MGMT is only one of several players.

The $\mathrm{O}^{6}$-methylguanine-DNA methyltransferase also causes resistance to chloroethylating agents like BCNU and the nitrosourea analogue, fotemustine (for review see Kaina et al, 2007). These agents are used in the therapy of metastatic melanoma either as a single agent (Li and McClay, 2002) or in combination with methylating agents, notably TMZ (Tas et al, 2007). Therapy with fotemustine has response rates of $\sim 20 \%$; only partial responses were observed with a median of several months. The poor outcome of metastatic melanomas to chemotherapy stresses the need for improved strategies. A prerequisite for this would be the detailed knowledge of how these drugs exert their cell killing effects in malignant melanoma cells.

Temozolomide methylates DNA forming, among other lesions, $\mathrm{O}^{6} \mathrm{MeG}$. The mechanism of apoptotic cell death triggered by $\mathrm{O}^{6} \mathrm{MeG}$ has been studied extensively in different cell systems, including rodent cells (Tominaga et al, 1997; Meikrantz et al, 1998; Ochs and Kaina, 2000; Roos et al, 2007b), human lymphocytes (Dunkern et al, 2003; Hickman and Samson, 2004; Roos et al, 2004), and malignant glioma cells (Roos et al, 2007a). It has become clear that $\mathrm{O}^{6} \mathrm{MeG}$ mispaired with thymine is the critical secondary pre-apoptotic DNA lesion. It has been proposed that the processing of $\mathrm{O}^{6} \mathrm{MeG} / \mathrm{T}$ mismatches by MutS $\alpha$-dependent DNA mismatch repair (MMR) gives rise to activation of ATR-Chk1 signalling (Caporali et al, 2004; Stojic et al, 2004) and DNA double-strand breaks (DSBs) that act as the ultimate trigger of the apoptotic pathway (Ochs and Kaina, 2000; Roos and Kaina, 2006). Alternatively, MutS $\alpha / \mathrm{MutL} \alpha$ bound to $\mathrm{O}^{6} \mathrm{MeG} / \mathrm{T}$ lesions may directly activate apoptotic signalling. Apart from the finding that ATR/ATRIP is activated in the presence of MutS $\alpha$-bound $\mathrm{O}^{6} \mathrm{MeG} / \mathrm{T}$ mismatches (Yoshioka et al, 2006), evidence for this model is scarce. Contrary to TMZ, fotemustine modifies DNA by chloroethylation, giving rise to $\mathrm{O}^{6}$-chloroethylguanine. This lesion undergoes spontaneous inter- and intra-molecular rearrangement to form a N1-guanine-N3-cytosine interstrand crosslink (ICL; Tong et al, 1982). Although several other adducts are also formed, these ICLs are believed to be responsible for the killing effect of chloroethylating agents. Because MGMT repairs $\mathrm{O}^{6}$-chloroethylguanine before the ICL can form, and $\mathrm{O}^{6} \mathrm{MeG}$ before the mismatch can form, the repair protein is considered as a key mechanism of resistance of tumour cells against fotemustine, TMZ, and other anticancer drugs with similar properties.

Although methylating and chloroethylating drugs are crucial in primary therapy of metastatic melanomas, it is not known how they exert killing effects in melanoma cells. In a recent study it was reported that TMZ does not induce apoptosis, but senescence in human melanoma cells (Mhaidat et al, 2007), which is surprising in view of the fact that other cell systems such as malignant gliomas undergo apoptosis very efficiently in response to TMZ (Roos et al, 2007a). For fotemustine, it has been shown that melanoma cells are killed by apoptosis (Passagne et al, 2003; Kissel et al, 2006), but detailed studies on the mode of cell death by this drug in melanoma cells are not available. Also, there is no systematic study (utilising the same cell model) for melanomas as to the role of MGMT, p53, and MMR proteins in the $\mathrm{O}^{6}$-alkylguanine-triggered killing response. Here, we investigated the mode of cell death induced by TMZ and fotemustine in a panel of human cutaneous malignant melanoma cell lines. Notably, we assessed the question of cell death pathways (apoptosis, necrosis) evoked by these drugs in melanomas. We provide, for the first time, evidence that TMZ is a potent inducer of apoptosis in melanoma cells. We also show that fotemustine has the ability to induce both apoptosis and necrosis at high level. We furthermore demonstrate the formation of DSBs $(\gamma \mathrm{H} 2 \mathrm{AX})$ and caspase activation, and elucidated the impact of MGMT, MMR, and p53 status on the response.

\section{MATERIAL AND METHODS}

\section{Cell culture and drug treatment}

The cell lines D03, D05, D14, MeWo, MeWo Fote40, MZ7, and SK29 were grown in RPMI-1640 medium containing $10 \%$ fetal calf serum, G361 was grown in McCoy's 5A medium containing 10\% fetal calf serum, A375 and RPMI7951 were grown in DMEM containing 10\% fetal calf serum, and Malme $3 \mathrm{M}$ was grown in DMEM containing $20 \%$ fetal calf serum. All cell lines were grown at $7 \% \mathrm{CO}_{2}, 37^{\circ} \mathrm{C}$ in medium containing $100 \mathrm{U} \mathrm{ml}^{-1}$ penicillin and $100 \mu \mathrm{g} \mathrm{ml}^{-1}$ streptomycin. SK29-MEL (Wolfel et al, 1995), MZ7-MEL cells (Lennerz et al, 2005), D03-, D05-, and D14-MEL (Pavey et al, 2004; Stark and Hayward, 2007), and A365, Malme 3M, G361, and RPMI7951 (Haapajarvi et al, 1999) cells were described previously. $N$-methyl$N^{\prime}$-nitro- $N$-nitrosoguanidine (MNNG; Sigma, Munich, Germany) stocks were prepared by dissolving the drug in dimethyl sulphoxide (DMSO) and then diluting with sterile $\mathrm{dH}_{2} \mathrm{O}$ to a $10 \mathrm{mM}$ concentration. Temozolomide (Schering-Plough, Kenilworth, NJ, USA) stocks, with $35 \mathrm{~mm}$ end concentration, were prepared by dissolving the drug in pure DMSO. The MNNG and TMZ stocks were filtered, aliquoted, and then stored at $-80^{\circ} \mathrm{C}$ till use. Fotemustine (diethyl1-[3(2-chloroethyl)-3-nitrosoureido]ethylphosphate; Muphoran, Servier Research International, Neuilly sur Seine, France) was prepared fresh for each treatment in a concentration of $1 \mu \mathrm{g} \mathrm{ml}^{-1}$ in one-third of ethanol and two-thirds sterile distilled $\mathrm{H}_{2} \mathrm{O}$. To deactivate the MGMT protein, $10 \mu \mathrm{M} \mathrm{O} \mathrm{O}^{6}$-benzylguanine $\left(\mathrm{O}^{6} \mathrm{BG}\right)$ was added to the cells $1 \mathrm{~h}$ before drug treatment.

\section{Determination of apoptosis}

$S u b-G_{1} \quad$ Non-adherent and trypsinised adherent cells were combined, suspended in cold PBS, and fixed in ice-cold $70 \%$ ethanol for a minimum of $30 \mathrm{~min}$. DNA in the cells was stained with propidium iodide (PI; $16.5 \mu \mathrm{g} \mathrm{ml}^{-1}$ ) in PBS after RNase $\left(0.03 \mu \mathrm{g} \mathrm{ml}^{-1}\right)$ digestion. For each sample 10000 cells were subjected to flow cytometric analysis using an FACS Calibur (Becton Dickinson, Heidelberg, Germany). The number of apoptotic cells was calculated using the computer program WinMDI 2.8 (Joseph Trotter, http://facs.scripps. edu/software.html).

Annexin V/PI This assay distinguishes between early apoptotic cells and late apoptotic/necrotic cells, by using annexin V/PI double staining of unfixed cells. Cells in the supernatant and trypsinised cells were combined and suspended in $50 \mu \mathrm{l}$ binding buffer (10 mM HEPES (pH 7.4), $140 \mathrm{~mm} \mathrm{NaCl}, 2.5 \mathrm{~mm} \mathrm{CaCl}, 0.1 \%$ BSA). Annexin V-FITC $(2.5 \mu \mathrm{l}$; BD Pharmingen, Heidelberg, Germany) was added to each samples. After 15 min incubation in the dark, $430 \mu \mathrm{l}$ binding buffer and $1 \mu \mathrm{g} \mathrm{ml}^{-1}$ PI per sample were added. The flow cytometric analysis was carried out using an FACS Calibur (Becton Dickinson). For each sample 10000 cells were analysed. The evaluation of the cell populations was performed using the computer program WinMDI 2.8 (Joseph Trotter). 


\section{Preparation of protein extracts}

For preparing whole-cell extracts, cells were washed in ice-cold PBS, harvested, and re-suspended in whole-cell extract buffer (20 mM Tris-HCl; pH 8.5, 1 mM EDTA, $1 \mu \mathrm{m} \beta$-mercaptoethanol, 5\% glycerol, $10 \mathrm{~mm}$ DDT, $0.5 \mathrm{~mm}$ PMSF, $1 \mathrm{~mm} \mathrm{Na}_{3} \mathrm{VO}_{4}$, proteinase inhibitor Complete; Roche, Mannheim, Germany). After sonication on ice (two times for 10 pulses) with a Branson sonifier (Cell Disruptor B15), output control $=4,40 \%$ Duty Cycle, the homogenates were centrifuged $\left(10000 \mathrm{~g}, 10 \mathrm{~min}\right.$ at $\left.4{ }^{\circ} \mathrm{C}\right)$, and the clear supernatants were stored at $-80^{\circ} \mathrm{C}$.

For fractionated extracts, cells were washed in ice-cold PBS, harvested, and re-suspended in fractionation buffer $A(10 \mathrm{~mm}$ HEPES-KOH; pH 7.4, $0.1 \mathrm{~mm}$ EDTA, $1 \mathrm{~mm}$ EGTA, $250 \mathrm{~mm}$ sucrose, $10 \mathrm{~mm}$ DDT, $0.5 \mathrm{~mm}$ PMSF, $1 \mathrm{~mm} \mathrm{Na}_{3} \mathrm{VO}_{4}$, proteinase inhibitor Complete; Roche). Cell membranes were disrupted by freezing in liquid nitrogen and thawing at $37^{\circ} \mathrm{C}$, four times (after thawing, the cell suspension was vortexed for $5 \mathrm{~s}$ ). After centrifugation of the homogenates $\left(700 \mathrm{~g}, 10 \mathrm{~min}\right.$ at $\left.4{ }^{\circ} \mathrm{C}\right)$ to separate the nuclei in a pellet, the supernatant, including the cytoplasmic fraction, was transferred to a new reaction tube whereas the pellet was kept on ice. The supernatant was cleared by centrifugation $\left(10000 \mathrm{~g}, 10 \mathrm{~min}\right.$ at $\left.4^{\circ} \mathrm{C}\right)$ and the pure cytoplasmic fraction was stored at $-80^{\circ} \mathrm{C}$. The pellet containing the nuclei was re-suspended in whole-cell extract buffer (20 mM Tris-HCl; $\mathrm{pH}$ 8.5, $1 \mathrm{~mm}$ EDTA, $1 \mu \mathrm{M} \beta$-mercaptoethanol, 5\% glycerol, $10 \mathrm{~mm}$ DDT, $0.5 \mathrm{~mm}$ PMSF, $1 \mathrm{mM} \mathrm{Na}_{3} \mathrm{VO}_{4}$, proteinase inhibitor Complete; Roche) and sonicated on ice with a Branson sonifier (Cell Disruptor B15), output control =4, 40\% Duty Cycle, two times for 10 pulses, the homogenates were centrifuged $(10000 \mathrm{~g}$, $10 \mathrm{~min}$ at $4{ }^{\circ} \mathrm{C}$ ) and the supernatant containing the nuclear proteins was stored at $-80^{\circ} \mathrm{C}$.

\section{Protein concentration determination}

Protein concentrations were determined using the Bradford method (Bradford, 1976). Bradford reagent (200 $\mu \mathrm{l} ; 0.01 \%$ G240 brilliant blue (Saba), 5\% ethanol, $10 \% \mathrm{H}_{3} \mathrm{PO}_{4}, 85 \% \mathrm{dH}_{2} \mathrm{O}$ ) was added to $10 \mu \mathrm{l}$ of a $1: 10$ dilution of the protein extracts. Following $15 \mathrm{~min}$ incubation in the dark, the absorption was measured by photometry at $595 \mathrm{~nm}$. The protein concentration was determined using a calibration curve with BSA protein, taken in parallel.

\section{Western blot analysis}

The method used here is based on the method by Renart et al (1979). Samples of $25 \mu \mathrm{g}$ of protein extracts were separated on a 7.5 or $12 \%$ SDS-polyacrylamide gel. Separated protein were blotted onto a nitrocellulose transfer membrane (Schleicher and Schuell, Dassel, Germany) in a Bio-Rad blot cell for $3 \mathrm{~h}$ at $300 \mathrm{~mA}$ using buffer consisting of $25 \mathrm{~mm}$ Tris- $\mathrm{HCl}, 86 \mathrm{~mm}$ glycine, and $20 \%$ methanol. The membranes were blocked for $1 \mathrm{~h}$ at room temperature in $5 \%$ (wt/vol) milk powder in TBS $(150 \mathrm{~mm} \mathrm{HCl}$, $20 \mathrm{~mm}$ Tris pH 7.6) containing $0.1 \%$ Tween 20 (TBS-Tween) and incubated overnight at $4{ }^{\circ} \mathrm{C}$ with the primary antibody $(1: 200-$ $1: 1000$ dilution $)$ in $5 \%(\mathrm{wt} / \mathrm{vol})$ milk powder or BSA in TBSTween. The membranes were washed three times for $10 \mathrm{~min}$ in TBS - Tween each, incubated for $1 \mathrm{~h}$ with a horseradish-peroxidasecoupled secondary antibody (dilution 1:4000) (Amersham Biosciences AB, Munich, Germany) in TBS-Tween and washed again three times for $10 \mathrm{~min}$ in TBS-Tween. For developing the membranes, a chemiluminescence detection system (Amersham Biosciences $\mathrm{AB}$ ) was used. Western blots were quantified by densitometric scanning of the blots. The antibodies used were antiPARP1 and anti-Erk2 (Santa Cruz Biotechnology, Heidelberg, Germany), anti-caspase-3 and anti-caspase-7 (Cell Signaling, New England Biolabs, Frankfurt, Germany), and anti- $\gamma$ H2AX (Upstate, Millipore, Schwalbach, Germany).

\section{Determination of MGMT activity}

The MGMT activity was determined as previously described (Preuss et al, 1995). It was expressed as fmol of $\left[{ }^{3} \mathrm{H}\right]-$ methyl transferred from radioactively labelled DNA to protein per $\mathrm{mg}$ of total cell extract protein.

\section{Mismatch repair assays}

The MMR activity was determined as previously described (Christmann and Kaina, 2000). For gel retardation assays, 29-nucleotide oligomers with the general sequence $5^{\prime}$-GGG CTCGAGCTGCAGCTGCTAGTAGATCT- $3^{\prime}$ were annealed to oligomers with the general sequence $5^{\prime}$-GGGAGATCTACTAGNA GCTGCAGCTCGAG- $3^{\prime}\left(n=\mathrm{C}\right.$ or T) and labelled with $\left[{ }^{32} \mathrm{P}\right] \mathrm{dATP}$ using polynucleotide kinase. After incubation with nuclear proteins DNA - protein complexes were separated on polyacrylamide gels.

\section{Statistics}

Statistical analysis was performed using the computer-based program GraphPad Prism. For comparing differences between two populations the unpaired $t$-test was performed. For regression fits, the linear equation and the exponential decrease equation was used.

\section{RESULTS}

First, we studied the response of a well-known melanoma cell line, MeWo, to the model $S_{\mathrm{N}} 1$-methylating agent MNNG. (This agent acts similar to TMZ and DTIC by inducing $\mathrm{O}^{6} \mathrm{MeG}$ adducts in the DNA.) As shown in Figure $1 \mathrm{~A}, \mathrm{MNNG}$ induces a time-dependent reduction in the fraction of $G_{1}$ cells, an accumulation of cells in $G_{2}$, and a dramatic increase in the level of apoptotic sub- $\mathrm{G}_{1}$ cells. This was most obvious late, that is $72-144 \mathrm{~h}$, after treatment. Quantification of the sub- $G_{1}$ population shows that apoptosis starts 2 days after MNNG treatment and increases with increasing post-exposure time (Figure $1 \mathrm{~A}$, right panel). This also holds true for TMZ that induced apoptosis 4 days after treatment (Figure 1B for representative histograms and time response of apoptosis of TMZ-treated MeWo cells). We should note that the dose of TMZ applied in these experiments $(50 \mu \mathrm{M})$ was rather low, that is below the maximal clinical dose level (optimal plasma peak level $\sim 100 \mu \mathrm{M})$. Pretreatment of MeWo cells with $\mathrm{O}^{6} \mathrm{BG}$ did not lead to amelioration of TMZ-induced apoptosis (Figure 1B, inset of right panel). This is in line with the finding that MeWo cells do not express detectable MGMT (Christmann et al, 2001).

Next, we investigated a panel of melanoma cell lines that originated from cutaneous malignant melanomas. As depicted in Figure 1C, all but one cell line included in this study (D05, G361, A375, Malme 3M, D03, D14, MeWo, SK29, and RPMI7951) underwent apoptosis upon TMZ treatment, as measured by sub$\mathrm{G}_{1}$. There were clear differences in the sensitivity of the cell lines, with RPMI7951 the most sensitive and G361 the most resistant. Similar experiments were performed with the chloroethylating drug fotemustine. As shown in Figure 1D, all but one melanoma cell line underwent apoptosis upon treatment, again with remarkably different sensitivities. D03 cells were the most sensitive and G361 cells were the most resistant. Interestingly, the onset of apoptosis was earlier for fotemustine- than for TMZ-treated cells; it was observed $24 \mathrm{~h}$ after the beginning of fotemustine treatment whereas for TMZ it was observed after 72-96 h (Figure 1B and data not shown). It is important to note that all experiments with these cell lines were performed under $\mathrm{O}^{6} \mathrm{BG}$ pretreatment conditions to deplete residual MGMT activity.

The induction of apoptosis by TMZ and fotemustine in melanoma cells was confirmed using annexin V/PI double staining 

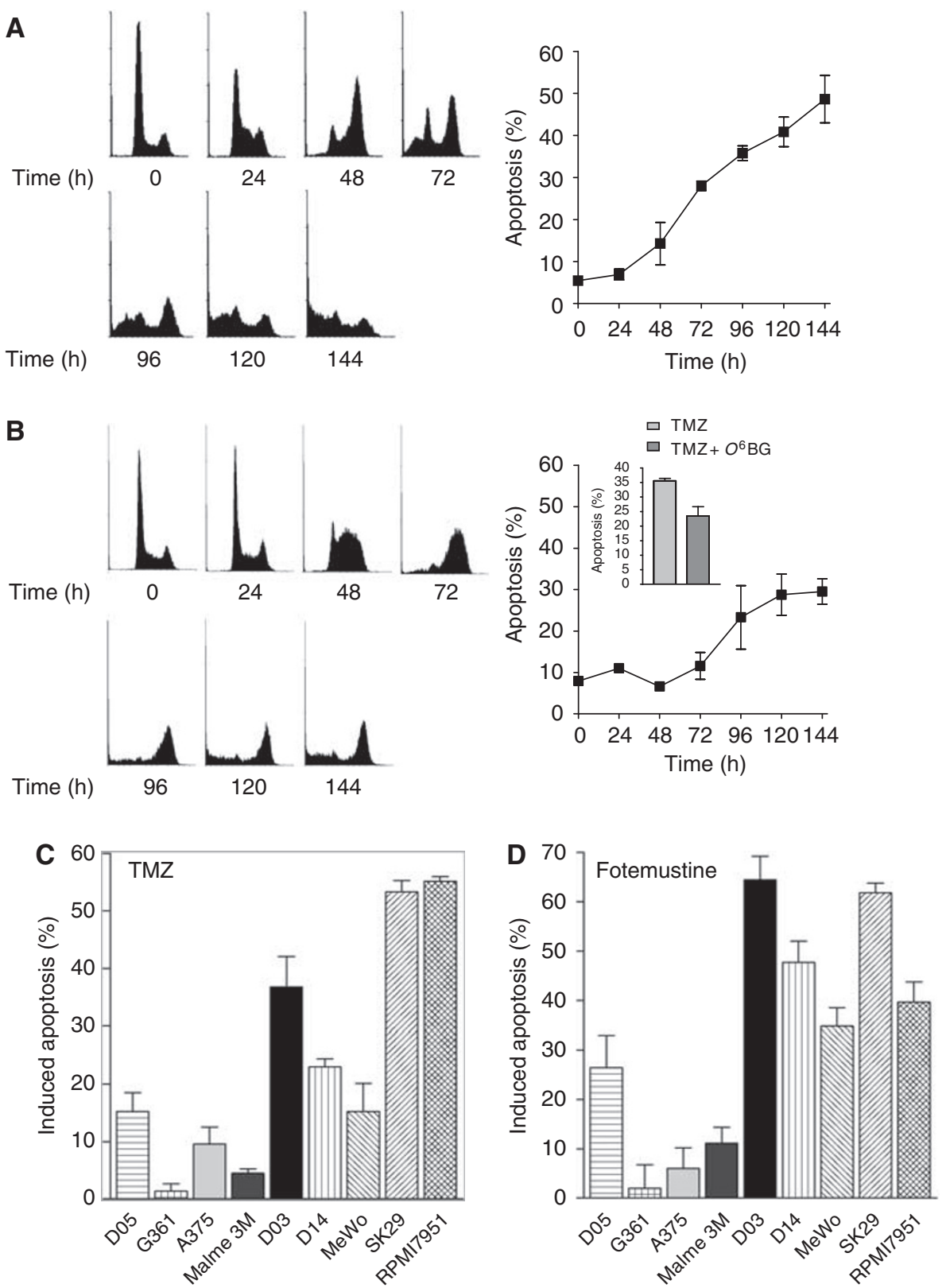

Figure I Apoptotic response after treatment with methylating agents in melanoma cells determined by quantifying the sub-G, population using flow cytometry. (A, left panel) Time-dependent flow cytometry histograms after treatment of MeWo cells with $5 \mu \mathrm{M}$ MNNG, (A, right panel) time-dependent determination of apoptotic response following treatment of MeWo cells with $5 \mu \mathrm{M}$ MNNG. (B, left panel) Time-dependent flow cytometry histograms after treatment of MeWo cells with $50 \mu \mathrm{M} \mathrm{TMZ,} \mathrm{(B,} \mathrm{right} \mathrm{panel)} \mathrm{time-dependent} \mathrm{determination} \mathrm{of} \mathrm{apoptotic} \mathrm{response} \mathrm{following} \mathrm{treatment} \mathrm{of} \mathrm{MeWo} \mathrm{cells} \mathrm{with}$ $50 \mu \mathrm{M}$ TMZ. (C) Frequency of apoptosis in nine melanoma cell lines after treatment with $50 \mu \mathrm{M} \mathrm{TMZ}$. Cells were pretreated with $10 \mu \mathrm{M} \mathrm{O}^{6} \mathrm{BG}$. (D) Apoptotic response in nine melanoma cell lines after treatment with $32 \mu \mathrm{M}$ fotemustine and $10 \mu \mathrm{M} \mathrm{O}^{6} \mathrm{BG}$. The baseline apoptosis level for the cell lines was as follows: D05, 5.3\%; G36I, 9.5\%; A375, 2.5\%; Malme 3M, II.I\%; D03, I5.5\%; DI4, 8.8\%; MeWo, 6.7\%; SK29, 5.2\%; RPMI795I, II.6\%.

and flow cytometry analysis, which allows for simultaneous quantification of apoptosis and necrosis/late apoptosis (Vermes et al, 1995). Data shown in Figure 2A (representative density dot blots) and Figure 2B (for quantification) revealed that $60-90 \%$ of cell killing resulted from apoptosis. The D14 cell line displayed nearly the same amount of apoptosis (annexin-V-positive cells) and necrosis/late apoptosis (annexin-V- and PI-positive cells) both after treatment with TMZ and fotemustine. Necrosis was induced in the cell lines at a frequency between 10 and $40 \%$.

Having shown that malignant melanoma cells are able to undergo apoptosis in response to TMZ and fotemustine, we studied the activation of caspases. We observed a clear activation of the executing caspases-3 and -7 upon TMZ and fotemustine treatment (Figure 2C for D14 cells and Figure 2D for SK29 cells). We also observed PARP cleavage, a hallmark of alkylation-induced apoptosis (Ochs and Kaina, 2000; Figure 2C and D). Overall, the data substantiate that malignant melanoma cells are able to undergo apoptosis after treatment with methylating and chloroethylating agents.

A major determinant of alkylating drug resistance is MGMT. Therefore, we determined the activity of this repair protein in the cell lines used in this study. They did not express detectable MGMT (D03, D14, SK29, MZ7, MeWo) or express MGMT at levels ranging between 100 and $400 \mathrm{fmol} \mathrm{mg}^{-1}$ protein (Figure 3A). For 
A
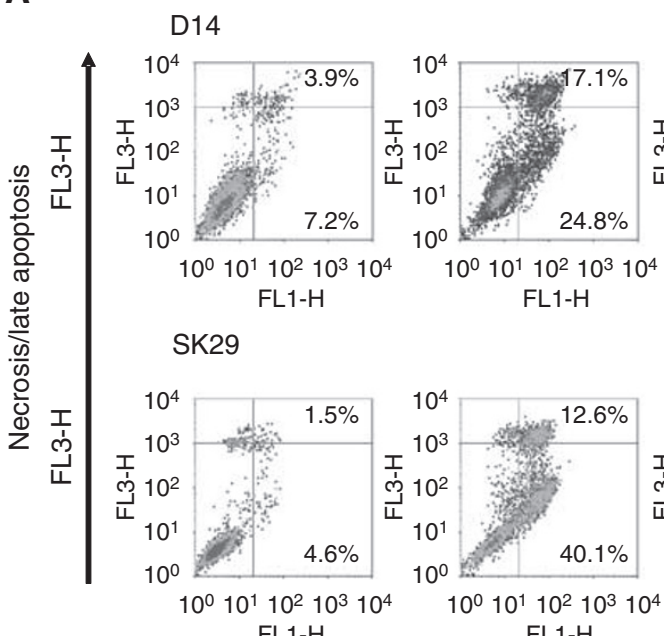

TMZ
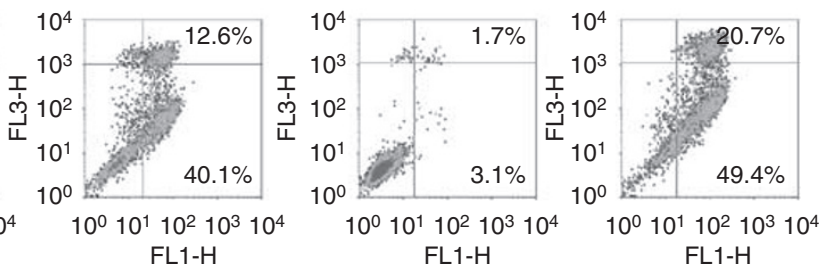

Apoptosis
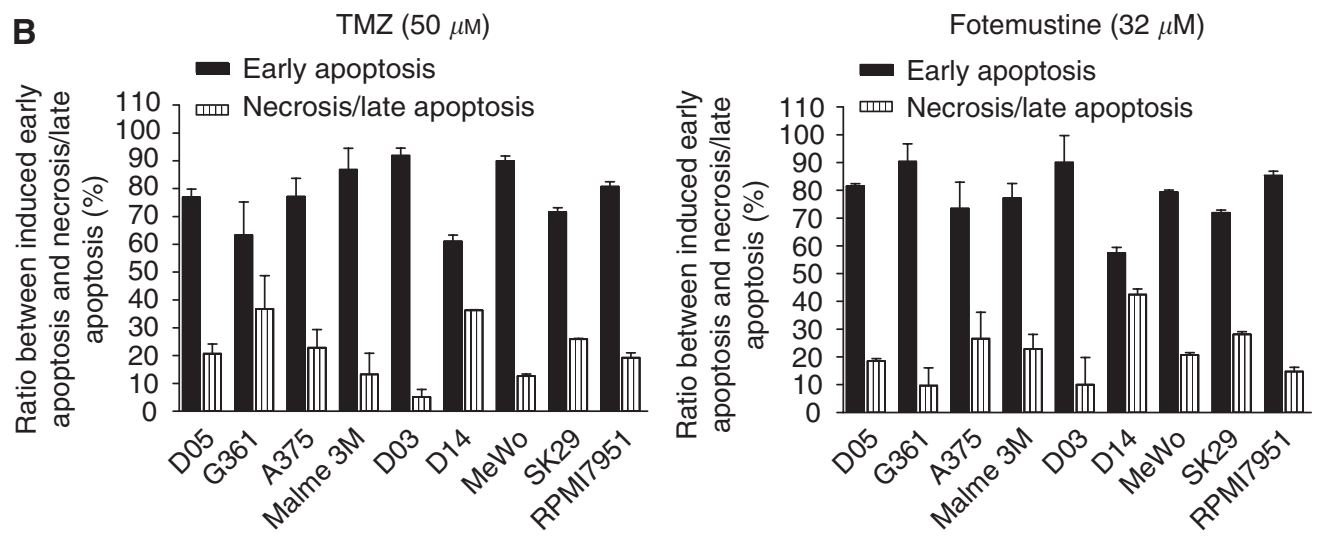

C
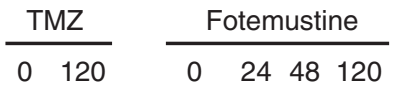

D
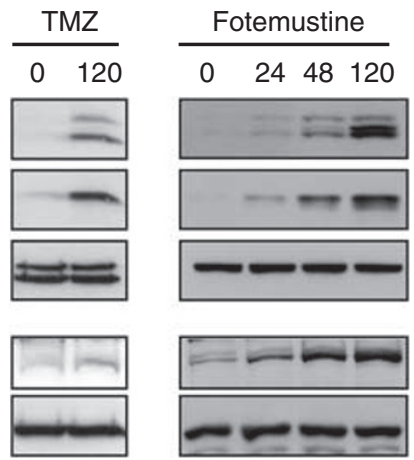

Figure 2 Quantification of the apoptotic and the necrotic/late apoptotic population by annexin V/PI double staining and western blot following TMZ and fotemustine treatment. (A) Representative flow cytometry density plots of cells not exposed and exposed to $50 \mu \mathrm{M}$ TMZ or $32 \mu \mathrm{M}$ fotemustine after I $44 \mathrm{~h}$ in the presence of $\mathrm{O}^{6} \mathrm{BG}(10 \mu \mathrm{M})$ in the melanoma cell lines DI4 and SK29, (B) ratio between apoptosis and necrosis/late apoptosis in TMZ- or fotemustine-treated cells after 144 h treatment in eight cell lines. For Malme 3M the TMZ time point was 196h. (C, D) Western blot analysis of effector caspase-3 activation documented by the cleavage products $\mathrm{p} / 7$ and $\mathrm{p} 19$, effector caspase-7 activation documented by cleavage product p20 and cleavage of PARP-I protein (c-PARP-I) following treatment with $100 \mu \mathrm{M} T M Z$ and $O^{6} \mathrm{BG}(10 \mu \mathrm{M})$, or $32 \mu \mathrm{M}$ fotemustine and $\mathrm{O}^{6} \mathrm{BG}(10 \mu \mathrm{M})$ in two representative melanoma cell lines DI4 (C) and SK29 (D).

comparison, we included a MeWo-derived cell line MeWoF40 that was generated by continuous fotemustine selection (Christmann et al, 2001), which expressed MGMT at very high level $\left(1160 \mathrm{fmol} \mathrm{mg}^{-1}\right.$ protein; Figure $\left.3 \mathrm{~A}\right) . \mathrm{MeWoF} 40$ cells are highly resistant to TMZ. If MGMT was depleted by $\mathrm{O}^{6} \mathrm{BG}$, apoptosis was induced at a high level, similar to MGMT-deficient MeWo cells (Figure 3B, left panel). Similar data were obtained with the cell lines D05, G361, A375, Malme 3M, and RPMI7951, all cell lines were MGMT positive and were sensitised following depletion of MGMT with $\mathrm{O}^{6} \mathrm{BG}$; in four of the five lines (except G361 which is extremely resistant even under MGMT-depleted conditions) the sensitisation was significant $(P<0.05$; Figure $3 \mathrm{~B}$, right panel). This shows that $\mathrm{O}^{6} \mathrm{MeG}$ is the major apoptotic trigger in melanoma cells treated with TMZ. 

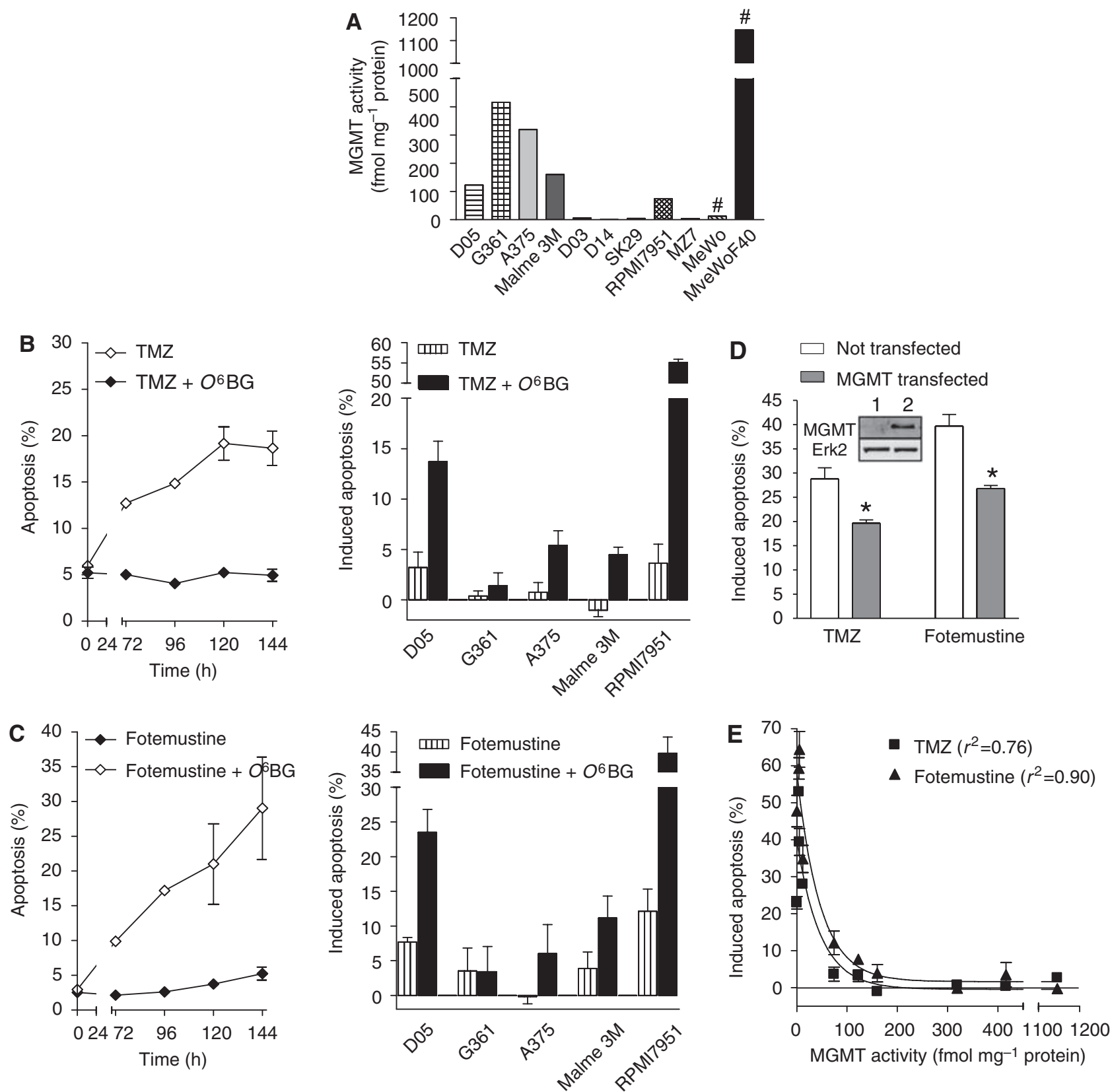

Figure 3 Determination of the influence of MGMT on alkylation at position $\mathrm{O}^{6}$ of guanine by treatment with TMZ and fotemustine. (A) Determination of MGMT activity (fmol $\mathrm{mg}^{-1}$ protein) in II melanoma cell lines. Time dependence of the apoptotic response as determined by quantifying the sub-G, population by flow cytometry after treatment with $50 \mu \mathrm{M} \mathrm{TMZ}$ with or without co-treatment with $10 \mu \mathrm{M} \mathrm{O}^{6} \mathrm{BG}$ in MeWoF40 cells (B, left panel). Apoptotic response of D05, G36I, A375, Malme 3M, and RPMI795 I cells to $50 \mu \mathrm{M}$ TMZ with or without co-treatment with O6 BG I44 h later. For D05, A375, Malme $3 M$, and RPMI795 I the sensitisation was significant $(P<0.05)$ (B right panel). Time dependence of the apoptotic response as determined by quantifying the sub-G, population by flow cytometry after treatment with $32 \mu \mathrm{M}$ fotemustine with or without co-treatment with $10 \mu \mathrm{M} \mathrm{O}^{6} \mathrm{BG}$ in MeWoF40 cells $(\mathbf{C}$, left panel). Apoptotic response of D05, G36I, A375, Malme 3M, and RPMI795 I cells to $32 \mu \mathrm{M}$ fotemustine with or without co-treatment with $\mathrm{O}^{6} \mathrm{BG}$ I $44 \mathrm{~h}$ later. For D05 and RPMI795I the sensitisation was significant $(P<0.05)(\mathbf{C}$, right panel). (D) Frequency of apoptosis as determined by quantifying the sub-G, population by flow cytometry after treatment with TMZ and fotemustine for $120 \mathrm{~h}$ in non-transfected and MGMT transient transfected SK29 cells (*decrease of apoptotic response in MGMT transfected cells in comparison to control is significant, $P<0.0 \mathrm{I}$ ). Expression of MGMT protein was determined by western blot analysis in non-transfected (lane I) and MGMT transient transfected SK29 cells (lane 2) at the time of drug treatment. (E) Induced level of apoptosis after TMZ $(50 \mu \mathrm{M})$ or fotemustine treatment $(32 \mu \mathrm{M})$ as a function of MGMT activity level. Data points were fitted to a line depicting an exponential decrease with plateau at $0 \%$ induced apoptosis. The correlation is significant.

MeWoF40 cells are also highly resistant to fotemustine. Under MGMT-depleted conditions, the cells approached the sensitivity of MeWo cells not expressing MGMT (Figure 3C, left panel) indicating that $\mathrm{O}^{6}$-chloroethylguanine, which is subject to repair by MGMT, is responsible for fotemustine-induced apoptosis in melanoma cells. This was confirmed with D05, G361, A375, Malme $3 \mathrm{M}$, and RPMI7951 cells when MGMT was inactivated by $\mathrm{O}^{6} \mathrm{BG}$ (Figure 3C, right panel). All cell lines but one (G361, which was completely refractory to apoptosis) showed an increased sensitivity to fotemustine when MGMT was inhibited. To further 


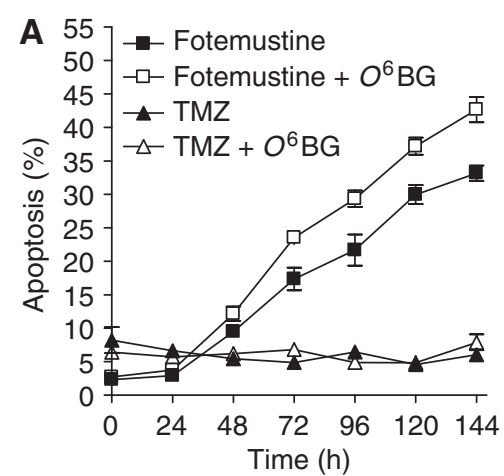

B
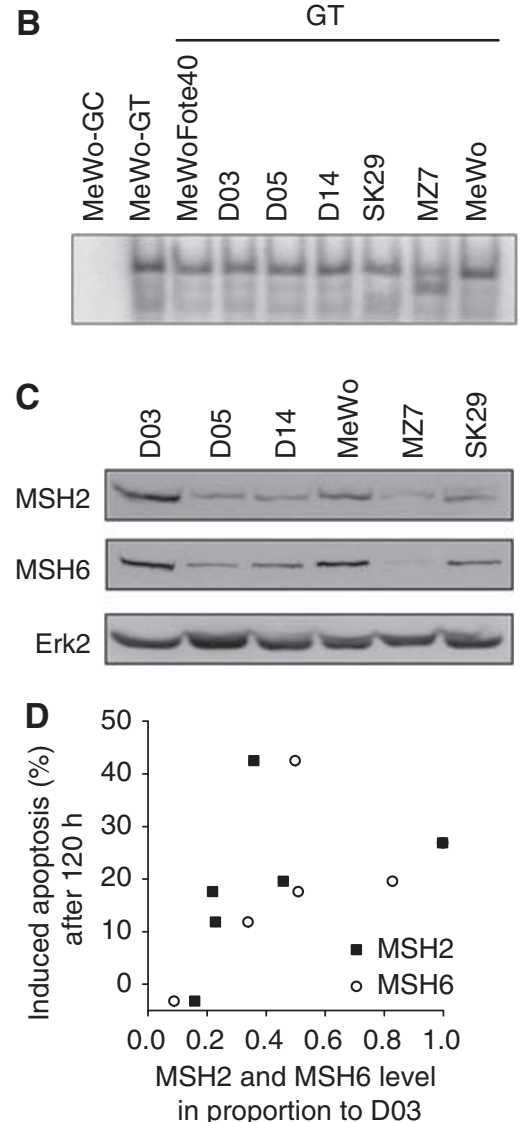

Figure 4 Influence of MMR on apoptotic response following $T M Z$ or fotemustine treatment in the MMR-impaired cell line MZ7. (A) Time dependence of the apoptotic response as determined by quantifying the sub-G, population by flow cytometry after treatment with $50 \mu \mathrm{M} \mathrm{TMZ}$ or $32 \mu \mathrm{M}$ fotemustine with or without co-treatment with $10 \mu \mathrm{M} \mathrm{O}^{6} \mathrm{BG}$. (B) Measurement of the $\mathrm{G} / \mathrm{T}$ binding activity of the MutS $\alpha$ complex in seven melanoma cell lines using the mismatch repair assay, (C) level of expression of $\mathrm{MSH} 2$ and $\mathrm{MSH} 6$ protein in different melanoma cell lines; Erk2 was used as loading control. (D) Induced level of apoptosis after TMZ treatment $(50 \mu \mathrm{M})$ as a function of $\mathrm{MSH} 2$ and $\mathrm{MSH} 6$ expression level (relative to D03 that was set to I). The correlation is not significant.

show the protective effect of MGMT, SK29 cells were transiently transfected with MGMT cDNA. The data show that ectopic overexpression of MGMT significantly reduced apoptosis both after treatment with TMZ and fotemustine (Figure 3D). Further, we compared the apoptotic response with the MGMT level expressed in the cell lines utilised in the study. There was a significant correlation between the MGMT activity level and the degree of resistance to TMZ- and fotemustine-induced apoptosis (Figure 3E). This shows that in melanoma cell lines MGMT is a decisive marker of alkylating drug resistance.

Comparing the apoptotic response of different melanoma cell lines, one cell line (designated MZ7) was highly resistant to TMZ and did not undergo apoptosis (Figure 4A, left panel for a timecourse experiment), although these cells did not express MGMT (Figure $3 \mathrm{~A}$ ). As expected, $\mathrm{O}^{6} \mathrm{BG}$ did not affect the response of these cells to TMZ (Figure 4A). When MZ7 cells were treated with fotemustine, they underwent apoptosis at a high level and $\mathrm{O}^{6} \mathrm{BG}$ slightly sensitised the cells (Figure 4A). Obviously, MZ7 cells have the ability to undergo apoptosis after exposure to fotemustine, but not TMZ. $\mathrm{O}^{6}$-MeG-triggered apoptosis requires DNA MMR, which is not essential for apoptosis induced by chloroethylating drugs (Liu et al, 1996; Pepponi et al, 2003). Therefore, we speculated that MZ7 cells are impaired in MMR. Indeed, the level of MutS $\alpha$ binding to a G/T mismatch-containing oligonucleotide was clearly different in MZ7 cells compared to the other melanoma cell lines studied, showing a protein-DNA complex with a lower molecular weight (Figure 4B). Thus, it appears that in MZ7 cells MMR is impaired, causing them to be highly resistant to TMZ. MutS $\alpha$ is composed of MSH2 and MSH6, the expression of which is shown in Figure 4C. MZ7 cells express a very low amount of MSH2 and MSH6 (at the border level of detection), which supports the inference that these cells are MMR impaired. The expression level of MSH2 and MSH6 in the other lines is higher than in MZ7 cells and quite variable. Importantly, comparing the response of the different cell lines, there was no correlation between MSH2 and MSH6 expression level and the sensitivity to TMZ (Figure 4D).

On the basis of data obtained with repair-defective mutants, it was proposed that $\mathrm{O}^{6} \mathrm{MeG}$ lesions are converted by means of MMR and DNA replication into DSBs that act as a final trigger of apoptosis (Ochs and Kaina, 2000). Therefore, we were interested in determining the level of DSBs in response to TMZ and fotemustine in different melanoma cell lines. As an indicator of DSBs we measured the total amount of phosphorylation of histone H2AX, which occurs in response to DSBs (Rogakou et al, 1998). As shown in Figure 5A, $\gamma \mathrm{H} 2 \mathrm{AX}$ was induced at different levels in the melanoma cell lines (Erk2 served as loading control). The highest level of induction was seen in D14, D03, and SK29 cells, the lowest level in MeWo, D05, and MZ7. Comparing the $\gamma \mathrm{H} 2 \mathrm{AX}$ induction level with the apoptotic response, a significant correlation was found between both end points (Figure 5B), which supports the hypothesis that DSBs are involved in TMZ-induced cell death.

A similar study was performed for fotemustine. Figure $5 \mathrm{C}$ outlines the time course of $\gamma \mathrm{H} 2 \mathrm{AX}$ induction. Unlike TMZ (data not shown), fotemustine induced $\gamma \mathrm{H} 2 \mathrm{AX}$ already after $24 \mathrm{~h}$, which is shown for the most sensitive lines D03, D14, and SK29. Overall, high level of $\gamma \mathrm{H} 2 \mathrm{AX}$ induction was found in D03, D14, and SK29 cells, and low level of induction in MeWo, D05, and MZ7. Interestingly, the level of $\gamma \mathrm{H} 2 \mathrm{AX}$ induction did not correlate at any of the time points $(24,48$, and $120 \mathrm{~h})$ with the level of fotemustineinduced apoptosis (Figure 5D). Thus, it appears that fotemustineinduced cell killing is based on a more complex mechanism in which DSBs may only be one of the several downstream components.

In previous studies we showed that p53 determines the sensitivity of glioma cells to TMZ and ACNU (Batista et al, 2007; Roos et al, 2007a). Therefore, we hypothesised that p53 may also be involved in alkylating drug resistance in melanoma cells. D05 cells are wild type for p53 (Packer et al, 2007); it becomes stabilised upon treatment with TMZ (Figure 6A) and fotemustine (Figure 6B), which is in line with DSBs formed in response to the treatments. Stabilisation of $\mathrm{p} 53$ provoked up-regulation of p21 as observed 48 and $72 \mathrm{~h}$ after TMZ and fotemustine treatment (Figure 6C), which indicates that p53 is functional. Transfection of 
A

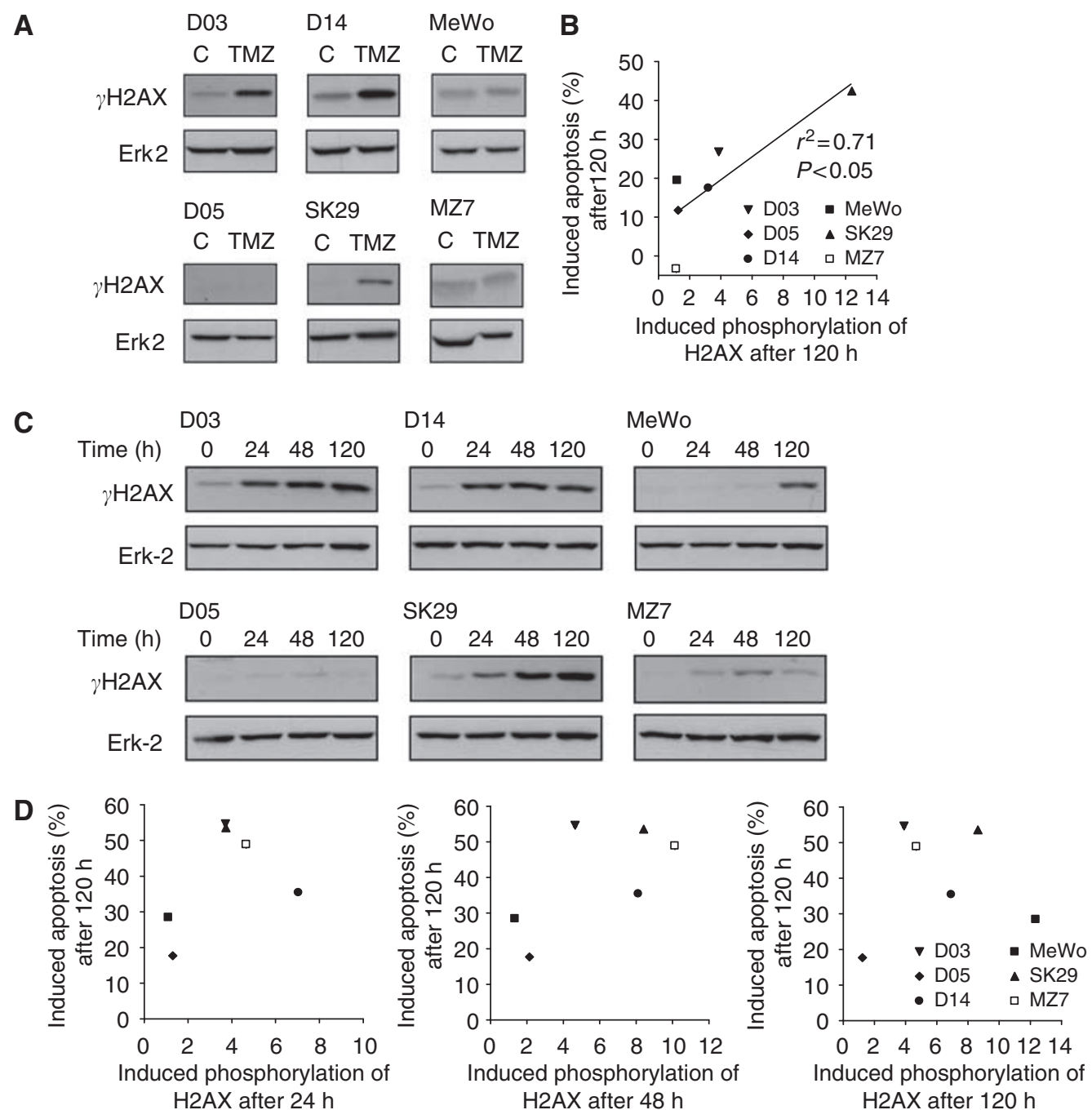

Figure 5 Phosphorylation status of $\mathrm{H} 2 \mathrm{AX}$ in six melanoma cell lines. (A) Expression level of $\gamma \mathrm{H} 2 \mathrm{AX}$ protein after treatment with $\mathrm{I} 00 \mu \mathrm{M} \mathrm{TMZ}$ and $\mathrm{O}^{6} \mathrm{BG}$ $(10 \mu \mathrm{M})$ for $120 \mathrm{~h}$, (B) significant correlation $(P=0.035)$ between induced $\mathrm{H} 2 \mathrm{AX}$ phosphorylation and induced apoptotic response as determined by quantifying the sub-G, population by flow cytometry $120 \mathrm{~h}$ after TMZ treatment (50 $\mu \mathrm{M})$. (C) Western blot analysis of $\gamma \mathrm{H} 2 \mathrm{AX}$ after treatment with $32 \mu \mathrm{M}$ fotemustine and $\mathrm{O}^{6} \mathrm{BG}(\mathrm{IO} \mu \mathrm{M})$ for 24, 48, and $20 \mathrm{~h}$, (D) not significant correlation between induced $\gamma \mathrm{H} 2 \mathrm{AX}$ phosphorylation for $24 \mathrm{~h}$ (left panel, $P=0.354$ ), $48 \mathrm{~h}$ (middle panel, $P=0.154$ ), and $120 \mathrm{~h}$ (right panel, $P=0.885$ ) and induced apoptotic response as determined by flow cytometry $120 \mathrm{~h}$ after fotemustine treatment.

p53 siRNA nearly completely abolished basal p53 expression and prevented TMZ- and fotemustine-induced p53 up-regulation as well as p53 (Ser15) phosphorylation (Figure 6A and B). However, down-regulation of p53 by siRNA transfection did not impact the level of apoptosis after TMZ treatment (Figure 6A, right panel), indicating p53 does not stimulate TMZ-induced cell death. It slightly enhanced the level of apoptosis after fotemustine (Figure 6B, right panel), which is in line with a protective role of p53 for chloroethylating agents by stimulation of DNA repair (Batista et al, 2007).

If p53 does not stimulate TMZ-induced apoptosis in melanoma cells one would expect p53 wild-type melanoma cells not to be more sensitive than p53 mutant cells. This appears to be the case: in Figure 6D we compared p53 wild-type and p53 mutant melanoma cells. The comparison revealed that the cells expressing p53 wild type are, on average, more resistant to TMZ than p53mutated cells (Figure 6D, left panel). p53 wild-type cells were also more resistant to fotemustine than lines expressing mutant p53 (right panel). As discussed below, the TMZ response is in marked contrast to the response of glioma cells.

\section{DISCUSSION}

First-line therapy of metastatic melanoma relies on the methylating and chloroethylating anticancer drugs DTIC, TMZ (Temodal), BCNU (Carmustine), and fotemustine (Muphoran). The mechanism of action of these agents at the DNA level has been well described. Temozolomide and DTIC methylate DNA at 13 sites (Kaina et al, 2007). One of the methylation products is $\mathrm{O}^{6} \mathrm{MeG}$ that, upon mispairing with thymine, activates MutS $\alpha$-dependent MMR that triggers apoptosis (Kaina et al, 1997; Tominaga et al, 1997; Meikrantz et al, 1998). Fotemustine and other chloroethylating nitrosoureas induce $\mathrm{O}^{6}$-chloroethylguanine, which gives rise to N1-guanine-N3-cytosine crosslinks by inter- and intra-molecular rearrangement $\sim 8 \mathrm{~h}$ after induction of the primary lesion (Brent et al, 1987). The molecular cell death pathways triggered by the critical DNA lesions are not predictable and appear to be dependent on the cellular background. Thus, the same DNA lesion can induce apoptosis, necrosis, or cellular senescence and growth arrest (Roos and Kaina, 2006), the reason for which is often unclear. For TMZ, there is evidence that DSBs are involved as 
A
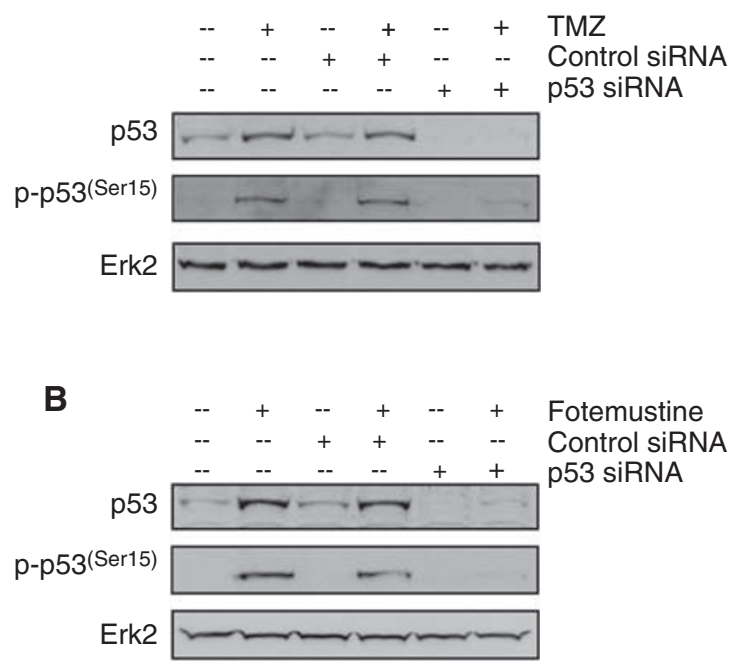

C
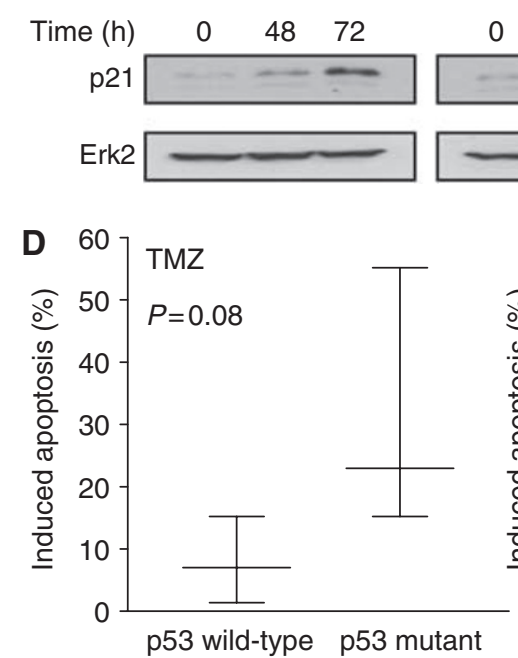

Fotemustine

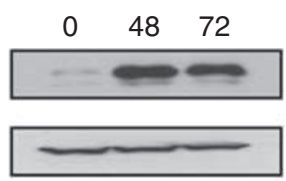

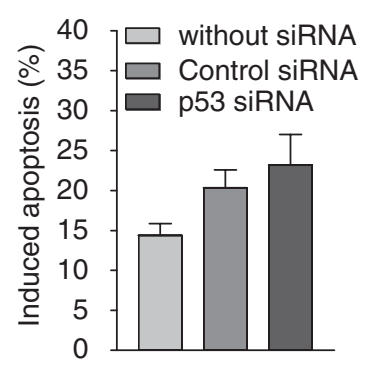

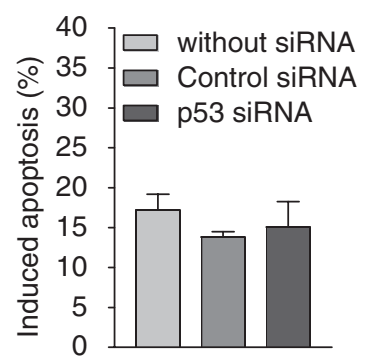

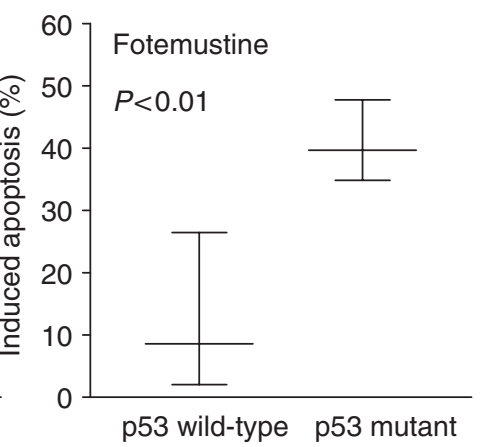

Figure 6 Activation of $\mathrm{p} 53$ and down-regulation by $\mathrm{p} 53$ siRNA. (A) D05 melanoma cells pretreated with $\mathrm{O}^{6} \mathrm{BG}(10 \mu \mathrm{M})$ were treated with TMZ (50 $\left.\mu \mathrm{M}\right)$ and $(\mathbf{B})$ fotemustine $(32 \mu \mathrm{M})$ and cells were harvested $72 \mathrm{~h}$ later. Control and p53 siRNA was transfected $24 \mathrm{~h}$ before the treatment with the drugs

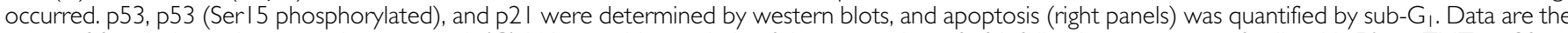
mean of four independent experiments \pm s.d. (C) Western blot analysis of the expression of p2 I following treatment of cells with $50 \mu \mathrm{M}$ TMZ or $32 \mu \mathrm{M}$ fotemustine. ERK2 was used as loading control. (D) Apoptosis induced in melanoma cells that are wild type or mutated for $\mathrm{p} 53$ I44 $\mathrm{h}$ following TMZ $(50 \mu \mathrm{M})$ (left panel) or fotemustine (32 $\mu \mathrm{M})$ (right panel). Data for the cell lines D05, G36I, A375, Malme 3M, DI4, MeWo, and RPMI795I for which the p53 status is known were taken from Figure IC and D.

a downstream trigger of apoptosis (Roos et al, 2009), which is yet unknown for fotemustine. It has also been shown that p53 has a critical dual function. In gliomas, p53 wild-type cells are more sensitive to TMZ, but more resistant to ACNU than p53 mutant cells, which was explained by up-regulation of CD95 death receptor or DNA repair (Batista et al, 2007; Roos et al, 2007a).

In this study, we elucidated the mechanism of death of malignant melanoma cells upon treatment with TMZ or fotemustine. We show that melanoma cells treated with the agents die by apoptosis and necrosis, with apoptosis being the major death pathway. Apoptosis was accompanied by caspase-7 and -3 activation and PARP cleavage. This is in contrast to a recent report stating that TMZ induces senescence, but not apoptosis in melanoma cells (Mhaidat et al, 2007). The failure to observe apoptosis in that study might be explained by the different post- exposure times that were used. Thus, in the study by Mhaidat et al (2007) the expression of apoptosis marker such as caspase- 3 and the cleaved PARP fragment was analysed $24-72 \mathrm{~h}$ after TMZ treatment. This seems to be a too short time period for apoptosis activation because TMZ-induced apoptosis is a late response that needs the passage of cells through at least two cell cycles after treatment (Kaina et al, 2007). Taking into account additional cellcycle inhibition due to high-dose treatment, apoptosis in some cell types such as gliomas will only be visible 4-6 days after treatment (Roos et al, 2007a). Using time-course experiments we found that melanoma cells start undergoing apoptosis $72 \mathrm{~h}$ after the addition of TMZ to the medium. Interestingly, fotemustine induced apoptosis at earlier times, starting $24 \mathrm{~h}$ after treatment. This is to be expected because the toxic effect of chloroethylating agents does not rely on MMR (Liu et al, 1996; Pepponi et al, 2003) and, therefore, cytotoxicity is exerted earlier, likely in the treatment cell 
cycle. This has been recently shown for the cyclophosphamide analogue mafosfamide that induces, similar to fotemustine, ICLs that trigger apoptosis in $S$ and $G_{2}$ phases of the treatment cell cycle (Goldstein et al, 2008).

For TMZ, we show that $\gamma \mathrm{H} 2 \mathrm{AX}$ is induced before apoptosis, which is indicative of the formation of DSBs. The frequency of DSBs was quantitatively correlated with the frequency of apoptosis. This supports a model where MMR generates gaps in the DNA (Mojas et al, 2007) that block replication, which leads to DSBs at collapsed replication forks in the second cell cycle after treatment (Ochs and Kaina, 2000; for review see Kaina et al, 2007). Thus, DSBs are postulated to act as a downstream trigger of $\mathrm{O}^{6} \mathrm{MeG}$-induced apoptosis. The quantitative correlation between $\gamma \mathrm{H} 2 \mathrm{AX}$ and sensitivity of melanoma cells to TMZ supports this notion and suggests that $\gamma \mathrm{H} 2 \mathrm{AX}$ might be a useful predictive indicator for the melanoma response to a methylating-agent-based therapy. Interestingly, for fotemustine, a correlation between DSBs and the apoptotic response was not found, which indicates that for chloroethylating agents DSBs are not (or not the only) downstream apoptosis-triggering lesion. Contrary to $\mathrm{O}^{6} \mathrm{MeG}$, ICLs prevent genes from being transcribed and, therefore, transcriptional inhibition could be involved. This conforms to previous findings with crosslinking agents for which transcriptional inhibition was shown to activate apoptosis (Ljungman et al, 1999; Arima et al, 2005; Goldstein et al, 2008). The question whether transcriptional inhibition has the main function in apoptosis triggered by therapeutic doses of fotemustine in melanoma cells is currently under study.

The cell death response of the melanoma lines was dependent on the MGMT level, which was shown by (1) the existence of an inverse correlation between the MGMT activity and TMZ-induced apoptosis, (2) inhibition of MGMT by $O^{6}$-benzylguanine that sensitised all MGMT-expressing melanoma lines, and (3) transfection with MGMT which caused TMZ apoptotic resistance. The data are in line with other reports showing that MGMT protects in vitro against TMZ-induced melanoma cell death (Pepponi et al, 2003; Pagani et al, 2007). They are in line with the view that $\mathrm{O}^{6} \mathrm{MeG}$ and $\mathrm{O}^{6}$-chloroethylguanine are the most critical primary DNA lesions induced by TMZ and fotemustine in melanoma cells. Two cell lines (out of 11) were identified that exhibited a highly resistant phenotype. Band-shift experiments with extracts of one of these lines (MZ7) revealed an abnormal complex bound to a G/T oligonucleotide. Also, the expression of $\mathrm{MSH} 2$ was very low and MSH6 was not detectable indicating that this melanoma cell line is
MMR defective. We should note that this line was generated from a malignant melanoma patient following treatment with DTIC. Therefore, the observed alteration in MMR might have occurred during therapy and might be an impressive example of acquired DTIC resistance. The extremely high level of resistance of another cell line, G361, to both TMZ and fotemustine is striking. It presumably relies on a downstream apoptosis execution defect, which is currently under study.

Abnormal levels of MMR proteins were reported in metastatic melanomas (Lage et al, 1999; Lo Muzio et al, 2000; Ma et al, 2002b; Shpitz et al, 2005). Because of this, and the high frequency of MMR-defective melanoma cell line (1 out of 11), down-regulation or impaired MMR might be considered (together with upregulation of MGMT) a cause of acquired resistance to TMZ and other methylating drugs. This, however, does not explain the resistance of melanoma cells to fotemustine, with a low response rate similar to TMZ of $\sim 20 \%$ ( $\mathrm{Li}$ and McClay, 2002). Therefore, it is possible that downstream defects, notably in the signalling and execution of apoptosis, are majorly responsible for melanoma drug resistance.

We also demonstrate activation of p53 upon TMZ and fotemustine treatment in melanoma cells. The apoptotic response of melanoma cells to TMZ was not related, however, to the p53 wild-type status. Thus, the cell lines expressing p53 wild type were, on average, more resistant to TMZ than p53 mutant cell lines (Figure 6D). Also, down-regulation of p53 by siRNA did not impact on TMZ sensitivity. This is in marked contrast to glioma cells that respond to methylating agents clearly better if p53 was wild type and worse if p53 was mutated or down-regulated (Roos et al, 2007a). For chloroethylating agents we found p53 wild-type melanoma cells again more resistant than p53 mutant cells (Figure 6D), which is in line with previous data obtained with glioma cells (Batista et al, 2007). Therefore, it appears that the role of p53 in the regulation of apoptosis upon TMZ treatment is different in melanoma cells than in gliomas and presumably other cancer cells. Whether and how this is related to the drug-resistant phenotype of melanoma cells is currently under study.

\section{ACKNOWLEDGEMENTS}

Work in the laboratory of BK was supported by KA724/13 and SFB 432/B7 grants from the German Research Foundation. VL was supported by grant SFB432/A1.

\section{REFERENCES}

Arima Y, Nitta M, Kuninaka S, Zhang D, Fujiwara T, Taya Y, Nakao M, Saya $\mathrm{H}$ (2005) Transcriptional blockade induces p53-dependent apoptosis associated with translocation of p53 to mitochondria. J Biol Chem 280: $19166-19176$

Bael TE, Peterson BL, Gollob JA (2008) Phase II trial of arsenic trioxide and ascorbic acid with temozolomide in patients with metastatic melanoma with or without central nervous system metastases. Melanoma Res 18: $147-151$

Balch CM, Buzaid AC, Soong SJ, Atkins MB, Cascinelli N, Coit DG, Fleming ID, Gershenwald JE, Houghton Jr A, Kirkwood JM, McMasters KM, Mihm MF, Morton DL, Reintgen DS, Ross MI, Sober A, Thompson JA, Thompson JF (2001) Final version of the American Joint Committee on Cancer staging system for cutaneous melanoma. J Clin Oncol 19: $3635-3648$

Batista LF, Roos WP, Christmann M, Menck CF, Kaina B (2007) Differential sensitivity of malignant glioma cells to methylating and chloroethylating anticancer drugs: p53 determines the switch by regulating xpc, ddb2, and DNA double-strand breaks. Cancer Res 67: 11886-11895

Bleehen NM, Newlands ES, Lee SM, Thatcher N, Selby P, Calvert AH, Rustin GJ, Brampton M, Stevens MF (1995) Cancer Research Campaign phase II trial of temozolomide in metastatic melanoma. J Clin Oncol 13: $910-913$

Bradford MM (1976) A rapid and sensitive method for the quantitation of microgram quantities of protein utilizing the principle of protein-dye binding. Anal Biochem 72: $248-254$

Brent TP, Lestrud SO, Smith DG, Remack JS (1987) Formation of DNA interstrand cross-links by the novel chloroethylating agent 2-chloroethyl(methylsulfonyl)methanesulfonate: suppression by $\mathrm{O}^{6}$-alkylguanine-DNA alkyltransferase purified from human leukemic lymphoblasts. Cancer Res 47: $3384-3387$

Caporali S, Falcinelli S, Starace G, Russo MT, Bonmassar E, Jiricny J, D’Atri S (2004) DNA damage induced by temozolomide signals to both ATM and ATR: role of the mismatch repair system. Mol Pharmacol 66: $478-491$

Chen JM, Zhang YP, Wang C, Sun Y, Fujimoto J, Ikenaga M (1992) $\mathrm{O}^{6}$-methylguanine-DNA methyltransferase activity in human tumors. Carcinogenesis 13: $1503-1507$

Christmann M, Kaina B (2000) Nuclear translocation of mismatch repair proteins MSH2 and MSH6 as a response of cells to alkylating agents. J Biol Chem 275: $36256-36262$ 
Christmann M, Pick M, Lage H, Schadendorf D, Kaina B (2001) Acquired resistance of melanoma cells to the antineoplastic agent fotemustine is caused by reactivation of the DNA repair gene MGMT. Int J Cancer 92: 123-129

Dunkern T, Roos W, Kaina B (2003) Apoptosis induced by MNNG in human TK6 lymphoblastoid cells is p53 and Fas/CD95/Apo-1 related. Mutat Res 544: $167-172$,

Goldstein M, Roos WP, Kaina B (2008) Apoptotic death induced by the cyclophosphamide analogue mafosfamide in human lymphoblastoid cells: contribution of DNA replication, transcription inhibition and Chk/ p53 signaling. Toxicol Appl Pharmacol 229(1): 20-32

Haapajarvi T, Pitkanen K, Laiho M (1999) Human melanoma cell line UV responses show independency of p53 function. Cell Growth Differ 10: $163-171$

Hickman MJ, Samson LD (2004) Apoptotic signaling in response to a single type of DNA lesion, O(6)-methylguanine. Mol Cell 14: 105-116

Hill DL (1975) Microsomal metabolism of triazenylimidazoles. Cancer Res 35: $3106-3110$

Kaina B, Christmann M, Naumann S, Roos WP (2007) MGMT: key node in the battle against genotoxicity, carcinogenicity and apoptosis induced by alkylating agents. DNA Repair (Amst) 6: 1079-1099

Kaina B, Fritz G, Mitra S, Coquerelle T (1991) Transfection and expression of human $\mathrm{O}^{6}$-methylguanine-DNA methyltransferase (MGMT) cDNA in Chinese hamster cells: the role of MGMT in protection against the genotoxic effects of alkylating agents. Carcinogenesis 12: 1857-1867

Kaina B, Ziouta A, Ochs K, Coquerelle T (1997) Chromosomal instability, reproductive cell death and apoptosis induced by $\mathrm{O}^{6}$-methylguanine in Mex-, Mex+ and methylation-tolerant mismatch repair compromised cells: facts and models. Mutat Res 381: 227-241

Kissel CK, Schadendorf D, Rockmann H (2006) The altered apoptotic pathways in cisplatin and etoposide-resistant melanoma cells are drug specific. Melanoma Res 16: 527-535

Lage H, Christmann M, Kern MA, Dietel M, Pick M, Kaina B, Schadendorf D (1999) Expression of DNA repair proteins hMSH2, hMSH6, hMLH1, $\mathrm{O}^{6}$-methylguanine-DNA methyltransferase and $\mathrm{N}$-methylpurine-DNA glycosylase in melanoma cells with acquired drug resistance. Int $J$ Cancer 80: $744-750$

Lennerz V, Fatho M, Gentilini C, Frye RA, Lifke A, Ferel D, Wolfel C, Huber C, Wolfel T (2005) The response of autologous $\mathrm{T}$ cells to a human melanoma is dominated by mutated neoantigens. Proc Natl Acad Sci USA 102: $16013-16018$

Li Y, McClay EF (2002) Systemic chemotherapy for the treatment of metastatic melanoma. Semin Oncol 29: 413-426

Liu L, Markowitz S, Gerson SL (1996) Mismatch repair mutations override alkyltransferase in conferring resistance to temozolomide but not to 1,3 bis(2-chloroethyl)nitrosourea. Cancer Res 56: 5375-5379

Ljungman M, Zhang F, Chen F, Rainbow AJ, McKay BC (1999) Inhibition of RNA polymerase II as a trigger for the p53 response. Oncogene 18: $583-592$

Lo Muzio L, Nocini P, Mignogna MD, Pannone G, Staibano S, Procaccini M, Rubini C, Fioroni M, Fanali S, Piattelli A (2000) Immunocytochemical detection of hMSH2 and hMLH1 expression in oral melanoma. Anticancer Res 20: $741-748$

Ma S, Egyhazi S, Martenhed G, Ringborg U, Hansson J (2002a) Analysis of $O(6)$-methylguanine-DNA methyltransferase in melanoma tumours in patients treated with dacarbazine-based chemotherapy. Melanoma Res 12: $335-342$

Ma S, Egyhazi S, Ringborg U, Hansson J (2002b) Immunohistochemical analysis of DNA mismatch repair protein and $\mathrm{O}^{6}$-methylguanine-DNA methyltransferase in melanoma metastases in relation to clinical response to DTIC-based chemotherapy. Oncol Rep 9: 1015-1019

Ma S, Egyhazi S, Ueno T, Lindholm C, Kreklau EL, Stierner U, Ringborg U, Hansson J (2003) $\mathrm{O}^{6}$-methylguanine-DNA-methyltransferase expression and gene polymorphisms in relation to chemotherapeutic response in metastatic melanoma. Br J Cancer 89: 1517 - 1523

Meikrantz W, Bergom MA, Memisoglu A, Samson L (1998) O6-alkylguanine DNA lesions trigger apoptosis. Carcinogenesis 19: 369-372

Mhaidat NM, Zhang XD, Allen J, Avery-Kiejda KA, Scott RJ, Hersey P (2007) Temozolomide induces senescence but not apoptosis in human melanoma cells. Br J Cancer 97: 1225 - 1233

Middleton MR, Grob JJ, Aaronson N, Fierlbeck G, Tilgen W, Seiter S, Gore M, Aamdal S, Cebon J, Coates A, Dreno B, Henz M, Schadendorf D, Kapp A, Weiss J, Fraass U, Statkevich P, Muller M, Thatcher N (2000) Randomized phase III study of temozolomide $v s$ dacarbazine in the treatment of patients with advanced metastatic malignant melanoma. J Clin Oncol 18: 158-166
Middleton MR, Lunn JM, Morris C, Rustin G, Wedge SR, Brampton MH, Lind MJ, Lee SM, Newell DR, Bleehen NM, Newlands ES, Calvert AH, Margison GP, Thatcher N (1998) $\mathrm{O}^{6}$-methylguanine-DNA methyltransferase in pretreatment tumour biopsies as a predictor of response to temozolomide in melanoma. Br J Cancer 78: 1199-1202

Mojas N, Lopes M, Jiricny J (2007) Mismatch repair-dependent processing of methylation damage gives rise to persistent single-stranded gaps in newly replicated DNA. Genes Dev 21: 3342-3355

Newlands ES, Blackledge GR, Slack JA, Rustin GJ, Smith DB, Stuart NS, Quarterman CP, Hoffman R, Stevens MF, Brampton MH (1992) Phase I trial of temozolomide (CCRG 81045: M\&B 39831: NSC 362856). $\mathrm{Br} J$ Cancer 65: 287-291,

Newlands ES, Stevens MF, Wedge SR, Wheelhouse RT, Brock C (1997) Temozolomide: a review of its discovery, chemical properties, preclinical development and clinical trials. Cancer Treat Rev 23: 35-61

Ochs K, Kaina B (2000) Apoptosis induced by DNA damage $\mathrm{O}^{6}$-methylguanine is $\mathrm{Bcl}-2$ and caspase- $9 / 3$ regulated and Fas/caspase- 8 independent. Cancer Res 60: 5815-5824

Packer LM, Pavey SJ, Boyle GM, Stark MS, Ayub AL, Rizos H, Hayward NK (2007) Gene expression profiling in melanoma identifies novel downstream effectors of p14ARF. Int J Cancer 121: 784-790

Pagani E, Falcinelli S, Pepponi R, Turriziani M, Caporaso P, Caporali S, Bonmassar E, D'Atri S (2007) Combined effect of temozolomide and hyperthermia on human melanoma cell growth and $\mathrm{O}^{6}$-methylguanineDNA methyltransferase activity. Int J Oncol 30: 443-451,

Passagne I, Evrard A, Winum JY, Depeille P, Cuq P, Montero JL, Cupissol D, Vian L (2003) Cytotoxicity, DNA damage, and apoptosis induced by new fotemustine analogs on human melanoma cells in relation to $\mathrm{O}^{6}$-methylguanine DNA-methyltransferase expression. J Pharmacol Exp Ther 307: 816-823

Pavey S, Johansson P, Packer L, Taylor J, Stark M, Pollock PM, Walker GJ, Boyle GM, Harper U, Cozzi SJ, Hansen K, Yudt L, Schmidt C, Hersey P, Ellem KA, O’Rourke MG, Parsons PG, Meltzer P, Ringner M, Hayward NK (2004) Microarray expression profiling in melanoma reveals a BRAF mutation signature. Oncogene 23: 4060-4067

Pegg AE (2000) Repair of $O(6)$-alkylguanine by alkyltransferases. Mutat Res 462: $83-100$

Pepponi R, Marra G, Fuggetta MP, Falcinelli S, Pagani E, Bonmassar E, Jiricny J, D'Atri S (2003) The effect of $\mathrm{O}^{6}$-alkylguanine-DNA alkyltransferase and mismatch repair activities on the sensitivity of human melanoma cells to temozolomide, 1,3-bis(2-chloroethyl)1-nitrosourea, and cisplatin. J Pharmacol Exp Ther 304: 661-668

Preuss I, Eberhagen I, Haas S, Eibl RH, Kaufmann M, von Minckwitz G, Kaina B (1995) $\mathrm{O}^{6}$-methylguanine-DNA methyltransferase activity in breast and brain tumors. Int J Cancer 61: 321-326

Renart J, Reiser J, Stark GR (1979) Transfer of proteins from gels to diazobenzyloxymethyl-paper and detection with antisera: a method for studying antibody specificity and antigen structure. Proc Natl Acad Sci USA 76: $3116-3120$

Rietschel P, Wolchok JD, Krown S, Gerst S, Jungbluth AA, Busam K, Smith K, Orlow I, Panageas K, Chapman PB (2008) Phase II study of extended-dose temozolomide in patients with melanoma. J Clin Oncol 26: 2299-2304

Rogakou EP, Pilch DR, Orr AH, Ivanova VS, Bonner WM (1998) DNA double-stranded breaks induce histone $\mathrm{H} 2 \mathrm{AX}$ phosphorylation on serine 139. J Biol Chem 273: $5858-5868$

Roos W, Baumgartner M, Kaina B (2004) Apoptosis triggered by DNA damage $\mathrm{O}^{6}$-methylguanine in human lymphocytes requires DNA replication and is mediated by p53 and Fas/CD95/Apo-1. Oncogene 23: $359-367$

Roos WP, Batista LF, Naumann SC, Wick W, Weller M, Menck CF, Kaina B (2007a) Apoptosis in malignant glioma cells triggered by the temozolomide-induced DNA lesion O(6)-methylguanine. Oncogene 26: 186-197

Roos WP, Christmann M, Fraser ST, Kaina B (2007b) Mouse embryonic stem cells are hypersensitive to apoptosis triggered by the DNA damage $O(6)$-methylguanine due to high E2F1 regulated mismatch repair. Cell Death Differ 14: 1422 - 1432

Roos WP, Kaina B (2006) DNA damage-induced cell death by apoptosis. Trends Mol Med 12: 440-450

Roos WP, Nikolova T, Quiros S, Naumann SC, Kiedron O, Zdzienicka MZ, Kaina B (2009) Brca2/Xrcc2 dependent HR, but not NHEJ, is required for protection against $O(6)$-methylguanine triggered apoptosis, DSBs and chromosomal aberrations by a process leading to SCEs. DNA Repair (Amst) 8: $72-86$

Shpitz B, Klein E, Malinger P, Osmolovsky G, Gochberg S, Bomstein Y, Bernheim J (2005) Altered expression of the DNA mismatch repair 
TMZ and fotemustine-induced apoptosis in melanoma cells

SC Naumann et al

proteins hMLH1 and hMSH2 in cutaneous dysplastic nevi and malignant melanoma. Int J Biol Markers 20: 65-68

Soengas MS, Lowe SW (2003) Apoptosis and melanoma chemoresistance. Oncogene 22: $3138-3151$

Stark M, Hayward N (2007) Genome-wide loss of heterozygosity and copy number analysis in melanoma using high-density single-nucleotide polymorphism arrays. Cancer Res 67: 2632-2642

Stojic L, Mojas N, Cejka P, Di Pietro M, Ferrari S, Marra G, Jiricny J (2004) Mismatch repair-dependent $\mathrm{G}_{2}$ checkpoint induced by low doses of SN1 type methylating agents requires the ATR kinase. Genes Dev 18: $1331-1344$

Tas F, Camlica H, Topuz E (2007) Temozolomide in combination with fotemustine in patients with metastatic melanoma. Cancer Chemother Pharmacol 62: 293-298

Tominaga Y, Tsuzuki T, Shiraishi A, Kawate H, Sekiguchi M (1997) Alkylation-induced apoptosis of embryonic stem cells in which the gene for DNA-repair, methyltransferase, had been disrupted by gene targeting. Carcinogenesis 18: 889-896

Tong WP, Kirk MC, Ludlum DB (1982) Formation of the cross-link 1-[N3deoxycytidyl),2-[N1-deoxyguanosinyl]ethane in DNA treated with $N, N^{\prime}$-bis(2-chloroethyl)- $N$-nitrosourea. Cancer Res 42: $3102-3105$

Vermes I, Haanen C, Steffens-Nakken H, Reutelingsperger C (1995) A novel assay for apoptosis. Flow cytometric detection of phosphatidylserine expression on early apoptotic cells using fluorescein labelled annexin V. J Immunol Methods 184: 39-51

Wolfel T, Hauer M, Schneider J, Serrano M, Wolfel C, Klehmann-Hieb E, De Plaen E, Hankeln T, Meyer zum Buschenfelde KH, Beach D (1995) A p16INK4a-insensitive CDK4 mutant targeted by cytolytic T lymphocytes in a human melanoma. Science 269: $1281-1284$

Yoshioka K, Yoshioka Y, Hsieh P (2006) ATR kinase activation mediated by MutSalpha and MutLalpha in response to cytotoxic $\mathrm{O}^{6}$-methylguanine adducts. Mol Cell 22: 501-510 